\title{
RONCE (Philippe), Guide des centres bouddhistes en
}

\section{France}

Paris, Noêsis, 1998, 536 p.

\section{Journals}

Édition électronique

URL : http://journals.openedition.org/assr/20943

DOI : $10.4000 /$ assr.20943

ISSN : $1777-5825$

Éditeur

Éditions de l'EHESS

Édition imprimée

Date de publication : 1 juin 2001

Pagination : 153

ISBN : 2-222-96704-X

ISSN : 0335-5985

\section{Référence électronique}

"RONCE (Philippe), Guide des centres bouddhistes en France ", Archives de sciences sociales des religions [En ligne], 114 | avril-juin 2001, document 114.103, mis en ligne le 19 août 2009, consulté le 24 septembre 2020. URL : http://journals.openedition.org/assr/20943 ; DOI : https://doi.org/10.4000/ assr.20943

Ce document a été généré automatiquement le 24 septembre 2020.

(C) Archives de sciences sociales des religions 


\section{RONCE (Philippe), Guide des centres} bouddhistes en France

Paris, Noêsis, 1998, 536 p.

RÉFÉRENCE

RONCE (Philippe), Guide des centres bouddhistes en France, Paris, Noêsis, 1998, 536 p. 